ISTANBUL

UNIVERSITY P R E S S

\title{
Rhetorical Activism in Politics: Stability Discourse and Pragmatic Practicality in Times of Crisis
}

\author{
Şermin TEKINALP ${ }^{1 \oplus}$, Seyra KESTEL ${ }^{2 \odot}$
}

\begin{abstract}
${ }^{1}$ Prof. Dr., Istanbul Esenyurt University, Department of Public Relations and Advertising, Istanbul, Turkey ${ }^{2}$ Res. Asst., Istanbul Esenyurt University, Department of Public Relations and Advertising, Istanbul, Turkey
\end{abstract}

ORCID: Ş.T. 0000-0002-9874-6059; S.K. 0000-0001-6105-8810

Sorumlu yazar/Corresponding author: Şermin Tekinalp,

İstanbul Esenyurt Üniversitesi, Halkla İlişkiler ve Tanıtım Bölümü, İstanbul, Türkiye

E-posta/E-mail: sermintekinalp@esenyurt.edu.tr

Geliș tarihi/Received: 09.03.2019 Revizyon talebi/ Revision requested: 20.03.2019

Son revizyon teslimi/ Last revision

received: 10.05 .2019

Kabul tarihi/Accepted: 29.05.2019

Atıf/Citation: Tekinalp, S., \& Kestel, S. (2019). Rhetorical activism in politics: Stability discourse and pragmatic practicality in times of crisis. Connectist: Istanbul University Journal of Communication Sciences, 56, 153-178. https://doi.org/10.26650/CONNECTIST2019-0022

\begin{abstract}
This article aims to investigate how successfully the dichotomy between stability and crisis is used as a medium of effective political activism and power in a critical election. The main question of the article is how the parties took advantage of the political climate in their political rhetoric to activate the mental cognitions of the majority at a time when Turkey was struggling with internal and external problems. In the framework of the research question, it is analyzed whether the parties, which were represented in the Turkish Parliament, utilized the dichotomy between stability and crisis in the context of pragmatic practicality or were lost obsessively in the normative, theoretically inductive long term ideals such as democracy, human rights and gender equality. In this context the term 'rhetorical activism' is associated to the term 'pragmatic practicality'. The principal objective of the article is to help increase consciousness of how the political rhetoric of the ruling party AKP (Adalet ve Kalkınma Partisi/Justice and Development Party) comprising the catchword "stability" contributed to the domination of the mental cognitions of the electorates, and so increased its votes by $10 \%$ in five months in November 1, 2015 elections.
\end{abstract}

Keywords: Rhetorical activism, crisis, stability, pragmatic practicality, idealism 


\section{EXTENDED ABSTRACT}

The principal objective of the article is to help increase consciousness how the political rhetoric of the ruling party AKP (Adalet ve Kalkınma Partisi/Justice and Development Party) comprising the catchword "stability" contributed to the domination of the mental cognitions of the electorates, and so increased its votes by $10 \%$ in five months in November 1, 2015 elections. The article investigates how the political parties made use of the political and social situation of the country in their political rhetoric to activate the voters' preferences. Drawing on this aim, the article focuses on the contextual critical analysis of the propaganda speeches of the four parties, (AKP/Justice and Development Party, CHP/ Republican People's Party, MHP/Nationalist Movement Party, HDP/Peoples' Democratic Party) given on October 31, 2015 on Turkish State Channel TRT1, broadcast just one day before the November 1 general election. TRT1 was chosen, because each party was allowed equal time to make their last propaganda speeches (10 minutes) a day before, on the eve of the elections. The propaganda speeches of each party is analyzed in the context of rhetorical activism, which can closely be associated to pragmatic purposive practicality, reinforced mainly by the theories of context Van Dick's (2010, p.10), commonsense (Fairclough, 1989, p. 89) and Aristotle's (1992) master rhetorical tools (pathos, logos) to project how each party utilized these 10 minutes.

Propaganda speeches of four political parties are recorded and categorized to investigate how parties conceptualized the political situation in Turkey, whether they pursued pragmatic practicality in the contexts based on the present or in the contexts of future-based idealistic goals. To analyze how parties conceptualized the political and social issues to get public consent, four discourse analysis tools of Gee (2011, pp. 150-184) are used. Situated Meaning Tool (SMT) covers the analysis of the meanings behind words to capture the parties' world views and values, Figured World Tool (FWT) helped us to analyze how parties refer to a picture of a simplified world view they take ideal, typical or normal and the Big " $D$ " Discourse Tool (BDDT) refers to how party spokespersons talk as members of the party's social and cultural background. The discourse topics to be investigated were categorized under six headings. They are 'stability', 'exhortation for voting', 'inveigling the voters', 'promotion of the party', 'condemnation', 'woman issues.' 
Topics in political speech may influence what people see as the most important information of text or talk (Duin \& Grayes, 1988). We have found that topics, if presented in the right time and setting with the right discourse materials (metaphor, metonymy, myth, emotional linguistic references, practical reasoning) correspond to the top levels of people's mental models. In the context of rhetorical activism and pragmatic practicality, we found that the AKP speaker tried to penetrate into the cognitive framework of the conservative audience by concentrating on facts at hand rather than long term idealistic goals and made the best use of the chaotic political and social situation, in other words, infused into the electorates' internal thought processes through a powerful Turkey image to end the crisis All the other parties, in the midst of increasing terror, spent more time on the constant criticisms of the AKP, mostly on the lack of democracy, corruption, poor governance, women issues and promotion of their party ideals. Drawing on Chilton's (2014, p. 204) assumption pointing out to the "fear of intruders and unknown people", we can claim that fear and rescue dichotomy stimulated automatically mental frames of the voters. We have seen that the AKP categorized its political priorities over and the advantages of a powerful Turkey ornamented with Islamic and nationalist myths. The use of stability metaphor has different connotations in the party messages. We strongly claim that, if controlled with an effective rhetoric, crises benefit a strong government in office and further empower its status. 


\section{INTRODUCTION}

The AKP (Adalet ve Kalkınma Partisi/Justice and Development Party), which held a majority of seats for 16 years in Turkey, obtained 258 seats in the Parliament with $40.9 \%$ of the votes in the June 7, 2015 election. The result was a shock to the party as it lost its majority so could not form a government. Only five months later, on November 1, 2015 the elections were renewed resulting in victory for the AKP who increased its votes over the June 7 elections by almost $10 \%$ with 317 seats. As for the political situation in Turkey before and during the election, four main issues attracted public opinion: Conflict between Turkey and the PKK (Partiya Karkerên Kurdistan) had been ongoing since 1984 and resulted in some 40,000-100,000 fatalities and great economic losses for Turkey as well as spiritual and physical damage to the Kurdish population. The'Peace Process' with the Kurdish movement did not generate a real confidence in public opinion. Another crucial problem area was the problems created by Gülen Movement (Hizmet) led by Fethullah Gülen, who made severe attacks to overthrow the Government. The Syrian war was another hot topic especially by the opposition. Turkish government's strategy was "based on the assumption that the USA and the West would put their weight behind toppling the Assad regime in the fall of 2011, as in Libya earlier in the same year." (Yetkin, 2016). Syrian war affected negatively the Turkey-Syria border security, army expenses, economy and tourism. Overwhelming influx of refugees into Turkey during the Syrian war had reached over 2.5 million by 2015. This made Turkey the host country with the largest refugee population in the world (Carpio \& Wagner, 2015).

When AKP came into power in 2002 by the support of religious conservative votes in the main, the current polarization between the secularists and Islamists changed its direction in favor of the religious conservatives. The rise of the new conservative capitalist new class has been influential in the transformation and moderation of the AKP. This conservative middle class played an important role across Anatolia in the transformation, globalization and moderation of the AKP in the first five years. However, poorly planned state and public expenditures, overconfidence, insistence mainly on souping up religious societies, conservative capitalists, clinging to uncontrolled power, ignoring the needs and demands of the opposition and impoverished sections of the society led the country to economic and political crisis. As the crisis started to show its visible effects in public, AKP adhered to a mythic nationalistic discourse promoting a sociocognitive context for stability and power against real and imaginary enemies inside and outside the country. 
The article focuses on the contextual critical analysis of the propaganda speeches of the four parties, (AKP/Justice and Development Party, CHP/Republican People's Party, MHP/Nationalist Movement Party, HDP/Peoples' Democratic Party) given on October 31, 2015 on Turkish State Channel TRT1, broadcast just one day before the November 1 general election. TRT1 was chosen, because each party was allowed equal time to make their last propaganda speeches (10 minutes) a day before, on the eve of the elections. It is assumed that each party, given such a limited time on the eve of a very critical election would concentrate on their core political messages in order to maximize perceptions. The propaganda speeches of each party is analyzed in the context of rhetorical activism, which can closely be associated to pragmatic purposive practicality, reinforced by the theories of context, relevance, commonsense and Aristotle's (1992) master rhetorical tools (pathos, logos) to project how each party utilized these 10 minutes.

\section{Background Literature}

Critical sociocognitive approaches to language use, discourse and power, discourse and discrimination, discourse and ideology and creating common sense by media messages grew into an international research methodology for critical studies (Fairclough, 1995, 2001; Fowler, 1991; Gamson, 1992; Gee, 2011; Smitherman \& van Dijk, 1988; Van Dijk, 1989, 2002, 2010; Wortham \& Reyes, 2015). Critical Discourse Analysis (CDA) primarily examines this control, dominance, abuse of power and inequality. This article investigates the discourse structures of political parties' propaganda speeches, how they legitimate their demands, reproduce or challenge relations of power and dominance, how they use discourse as a tool of power, authority, oppression, perception management and persuasion, how they are divided between idealism and materialism, in what meaning they use conceptual instruments such as metaphors and metonymies. To understand the sociocognitive structure of the discourse we have to refer to certain theories and assumptions which will contribute to understanding how power and perception management is reproduced. Aristotles' (1992) widely discussed rhetorical tools, pathos and logos, form the interrelated elements of the persuasive arts. Pathos appeals to feelings and emotions such as excitement, fear, love, and patriotism. Logos, which appeals to logic, means to convince audience by use of reasonable explanations. The AKP, for example, focused its political campaign on a powerful one-party rule and stability by referring to inside and outside dangers and created a mental frame that no other party has the capacity to perform the demanding tasks for the country. 
Context model of Van Dijk (2010) claims that political situation affects speech. "It is not social situation that influences (or is influenced by) discourse, but the way the participants define such a situation" (p. 10). Edelman's (1977, p. 47) example attracts attention to how a contextual reality was distorted by the political rhetoric during President Kennedy's administration on the threat of Soviet missiles. They did not show "the maintenance of American missiles in Turkey, a few miles from the borders of the Soviet Union, as creating a crisis, but chose to define Russian missiles in Cuba as an intolerable threat." Drawing on the theoretical conclusion of Waisbord (2012, pp. 438-440), we can put forth that the strength and effect of a speech cannot be analyzed without reading the cultural and ideological DNA of a nation and the speaker. These assumptions simply indicate that discourse is shaped (or distorted) for power, economic and political interests in line with the expectations of the nation.

Common Sense Theory assumes that "a dominant discourse is subject of naturalization" (Fairclough, 1989, p. 89). Drawing on the theory, we can argue that AKP's political agenda, which were constructed on domestic and global enemies and effectively supported by the mainline media, have created a common sense consensus. The theory explains how power dominates sociocognitive frames of brains and is perceived as natural. Politicians usually apply to common fears of people such as enemies, terrorists, chaos, economic collapse, underdevelopment, unemployment, etc. As Chilton (2014, p. 204) points out "Fear of intruders and unknown people... might have an innate basis and be stimulated automatically in the political use of language. In the analysis we also investigate how parties make use of socio-economic fears.

\section{AIM AND METHODOLOGY}

\section{Aim}

The article investigates the power of rhetorical activism and its means leading to success. By 'pragmatic practicality' we mean concentration on facts rather than ideals, meeting political problems with practical solutions rather than ideological ones to secure practical goals. In the study we hypothesize that among all other reasons, pragmatic practicality making the best use of the political situation (in our case, crisis) at hand instead of long-term idealistic goals (in our sample, women's rights) and canalizing electorates' perceptions to stability and security played a 
great role in the election results. The literature is reevaluated in the context of political activism, which is a policy of taking direct, and often militant action to achieve a political and social end. Drawing from this description, we can put pragmatic practicality into the category of most effectual means of rhetorical activism to achieve an end in politics. In broader terms, we can conceptualize activism in two contexts: Rhetorical (political propaganda speeches, political debates) and operational (demonstrations, protests, strikes, etc.). This paper analyzes the propaganda speeches of four political parties broadcast in TRT on the eve of the November 1, 2015 general election to find out the tools of rhetorical activism in the context of pragmatic practicality to affect the electorate.

\section{Methodology}

To analyze how parties conceptualized the political and social issues to get public consent, Critical Discourse Analysis (CDA) is chosen as research technique, because it deals with social problems, power relations, political issues (Fairclough \& Wodak, 1997, pp. 271-280). Gee's (2011, pp. 150-184) critical analysis tools are used to explore the meanings behind the nuanced words/phrases of the party speakers. Situated Meaning Tool (SMT) covers the analysis of the meanings behind words to capture the parties' world views and values, Figured World Tool (FWT) helped us to analyze how parties refer to a picture of a simplified world view they take ideal, typical or normal and the Big " $\mathrm{D}$ " Discourse Tool (BDDT) refers to how party spokespersons talk as members of the party's social and cultural background.

\section{Sampling and Categorization of the Discourse Topics}

Propaganda speeches of the four political parties broadcast in State Television Channel TRT1. These speeches are recorded and categorized to investigate in which mental frame and how parties conceptualized the political situation in Turkey. Did they pursue pragmatic practicality in the contexts based on the present or on the future story or in the context of future-based idealistic goals?

The discourse topics were categorized under six headings and the minutes each party allocated for each topic were calculated. The categorization involved 'stability' (commitments for a stable and peaceful Turkey), 'exhortation for voting' (encouraging citizens in the context of their story to go to ballot box), 'inveigling the electorate' 
(praising voters by appealing to religious, traditional or ideological codes in salutations), 'promotion of the party' (highlighting their mission and commitments), 'condemnation' (criticizing opposition parties or other nations in the context of their cognitive mental frames), 'woman issues' (gender equality, democracy, human rights in the context of idealistic goals).

\section{FINDINGS}

Data obtained as a result of the critical discourse analysis of the propaganda speech of the AKP Prime Minister, Ahmet Davutoğlu broadcast in State Television Channel TRT1 focusing mainly on "stability" and "power":

\section{Stability for a Powerful Turkey (04.55 mins)}

The Prime Minister draws two very simplified contradictory world pictures between Turkey and conceptualizes a rigid dichotomy between fear of chaos and stability (FWT). He thus addresses to the emotional centers of the electorates' brain (pathos) to share a common view about what is harmful, good-evil, just-unjust and pragmatically attempts to rationalize his mythical focal priority by situating Turkey (SWT) as an island of stability. Charteris -Black $(2014$, p. 7) calls this 'epideictic' oratory originating from Greek Word 'show' or 'display'. He pragmatically reinforces the importance of stability by associating it to the story of democracy and development (logos), because he expects that the audience already knows the cognitive framework of his hints and relies on them to fill in the gaps and details (relevance theory).

The metonymy of 'one party rule' corresponds to the peaceful Turkey under AKP's rule. The Prime Minister makes a very simplified practical reasoning (FWT) by using two contradictory concepts (the stable versus the unstable) to emphasize the difference not only between the AKP and other parties, but also the Turkey under AKP's rule and all the other nations. In the context of logos (reasoning) incomplete syllogism (enthymeme) is a classical political persuasion method. Peace is practically associated in broader sense with pragmatic simple reasoning to Quranic "halal and good votes" (lawful, permissible by God), which is suitable to the party's ideological background (BDDT) and that of the religious electorates. By religious metaphors he activates the unconscious and mythic emotional responses in electorates' mental frames (pathos). 
The Prime Minister pragmatically conceptualizes the fear of terrorists by relating it to the increase of terrorism after the results of 7 June elections, in which AKP had lost its majority in the Parliament (logos: enthymeme). This means that AKP governance is a must to end terrorism and voters' fears. He therefore emphasizes in broader terms the inevitability of stability to make democratic reforms with a very practical reasoning (logos: enthymeme). "Menzil" metaphor, which denotes AKP's background (BDDT) and covertly implies a Turkey transformed into an Islamic system (relevance theory), is an Arabic word meaning in the above context 'the last point of the destination'. Associated with the "menzil" metaphor, AKP quite frequently uses the 'word' and 'road' metaphors pointing to their holy mission to arouse the electorate's feelings in such a way to gain sympathy (Aristotle's pathos).

On the 2nd of November, what kind of Turkey do you want to see? Do you want an unstable Turkey that looks to the future with fear or a Turkey hopeful for the future that promises democracy?... In many countries millions of people are protesting against their governments in streets for unemployment...6 to 7 neighboring countries are struggling with serious political crisis...Turkey has been an island of stability and development for 13 years... Everybody should concentrate on just a single thought. Look! We promise you stability. We want a developed Turkey, stability is a must...During one party rule, the country has been more secure, more peaceful and more developed... We promise you stability. Other parties do not promise you stability. Why? Because they have no chance to come to power by themselves. 'Inşallah' (if God wishes) AKP will come to power with your 'helal' (halal) and good votes and, thus, Turkey will experience another four stable years...We promise you peace, security and a democratic environment in such unstable times...Look! After the 7 June election results, all the terror organizations (PKK, DHKP-C, ISID), started to attack, fancying that Turkey will fall into a management void... We strived to take them down a notch day and night...To keep this peaceful and secure environment, we have to enhance democracy and make political reforms...We promise you a civil constitution...A political environment totally democratic, cleaned out from coup context. To fulfill this aim we need your support, your prayers and your votes... We have a message and a road to walk on... Support us, empower us, pray and vote for us... Thus our road will take us to our target (menzil). 


\section{Exhortation For Voting (02.15 mins)}

To incite the electorate to vote, the prior concern of the speaker is security and the use of votes freely in terror areas. He attempts to appeal to the ordinary electorate's cognitive mental frames by simplified practical populist reasoning and over flattering statements: "No pressure and terror is more crucial than your free will.," 'Your votes are all blessed and valuable." is an exaggerated pragmatism buried in profound mythic cognitions.

Go to the ballot boxes confidently in peace... Use your votes with your free will in accordance to your decision... No pressure and terror is more crucial than your free will... I especially want to address my citizens in the South-East who would worry about the security of the elections in the region. Never hesitate to use your votes in peace as before. No pressure or terror is more crucial than your free will... (He addresses the young and disabled voters) Like others your votes are all blessed and valuable...Use your votes with your free will... (pathos, BDDT)

\section{Inveigling the Electorate (00.56 mins)}

The following quotation displays that the Prime Minister talks as a member of his social and cultural background through time and history (BDDT) and provides us with evidence with AKP's cultural and religious background. The contradictory terminologies of 'hayır/şer' (good/evil) is Quranic and prevails mostly in Islamic discourses, in which the word 'hayır' is preferred to secular substitute "iyi" (good); 'şer' to 'kötü' (bad). The cognitive references to conventional Islamic laudatory phrases such as "sizlerin huzurundayım" (I am in your presence), "hayırlı günler" (good days), reflects the highly reverential conservative and religious profile of the party (pathos). He salutes the audience with this reverential Islamic style of rhetoric.

Metaphoric or metonymic use of language reflects the cultural identity of the participants in a communication process (Chilton, 1985; Lakoff, 1993; Lakoff \& Johnson, 1980; McGlone, 1996). As Lakoff (1993) argues, figurative language is mediated by unconscious metaphoric correspondences that structure human concepts, or as stated by Gibbs (1996, p. 309), metaphor "is a specific mental mapping that influences a good deal of how people think, reason, and imagine in everyday life". "It is through metaphor, metonymy, and syntax that linguistic references evoke mythic cognitive structures in people's minds" (Edelman, 1977). On the version of this view, we claim that the Prime 
Minister uses the language to arouse emotions (pathos) for pragmatic purpose. The myth of grandfathers who shed their blood for this country is quite often used in Turkish political rhetoric. Metonymic evocation of 'shedding blood' for this country covers a larger structure of beliefs: Şehit (martyr) who died for this country, nationalism, enemies of the country. 'Şehit' is the highest honor accorded to the dead in Islam. If you have a 'word to say' and a 'road to walk on the way of Islam and Allah evokes mythic influence arousing feelings. They simplify issues by establishing trust for the AKP that is walking on the way of Allah. "If you have a word to say (if you prefer AKP) and'a road to walk on' (the way we are directing you), "you only rely on Allah and the nation."

...I wish you good ("hayırlı") days. I hope this election will be "hayırlı" for our country, for all humanity and for each of you. We all came into your presence... This country is yours...Your grandfathers shed blood and lost their lives in the independence war. Each of your children will have rights in this country... None is superior to the other... If you have a word to say and a road to walk on, you only rely on Allah and the nation...। wish this election will be good ("hayırlı") for our people, for our heart geography ("gönül coğrafyası") and for all humanity... I promise you "hayırlı" election and a future with the prospect of a Turkey that we will be proud of, "inşallah" (if God wishes).

\section{Promotion of the Party (01.33 mins)}

In the following quotation 'Great Turkey' metonymy, which is a substitution of an attribute to great projects, reflects the social and cultural background of the AKP (BDDT) as well as the expectations engraved into the cognitive mental frames of its supporters. Development and greatness is associated only with tangible ostentatious construction and production projects rather than forming and pursuing ideals like human rights, democracy, gender equality, etc. The Prime Minister pursues pragmatic practicality by referring to a picture of a simplified world view, which is situated as ideal by the party (SMT).

We promise you to prospect a great Turkey...A Turkey which will be in the greatest ten in the global economy... A Turkey who is building the greatest airport in the world...A Turkey that has built three-storey tunnel under the Bosphorus ... A Turkey that will build Canal Istanbul...A Turkey that has built its own tanks...national instruments and weapons for defense ...A Turkey developing with totally national production... As Turkey grows, you will get a bigger share from the welfare. We observe the gap between the need and claim of wide sections of the society... 


\section{Condemnation}

Null.

\section{Woman Issues}

Null.

Data obtained as a result of the critical discourse analysis of the propaganda speech of the CHP leader Kemal Kilıçdaroğlu broadcast in the State Television Channel TRT1 focusing mainly on the "promotion" of the CHP:

\section{Stability for Honourable Future (00:10 mins)}

The quotation below points out the promise of the CHP Leader to the electorate a 'peaceful' and 'honorable future.' He does not focus on the current events which destroy peace, but situates a Turkey with an honorable future (SMT). By the'honorable future' locution, he alludes to the ideals of democracy, respectable governance etc., which can be achieved in the long-term process. CHP, founded in 1923, has been a beacon for Turkish progressivism, which involved deep-rooted reformist ideologies (democracy, justice, equal distribution of wealth, gender equality, and reforms in every area) rather than pragmatic practicalities (BDDT). The speaker wants the electorate to use their votes for a Turkey the party is dreaming of. However vague, he implies a more democratic Turkey, albeit rather ambiguously.

On 1 November we will go to the ballot boxes. The key of a peaceful, honourable future, of a happy Turkey is in our hands... There is only one month to construct the Turkey we are dreaming of. I want you to give us sole authority to design the Turkey we are dreaming of. With love and respect.

\section{Exhortation for Voting (00.15 mins)}

The speaker wants the electorate to use their votes for a Turkey the party is dreaming of. However vague, he implies a more democratic Turkey, albeit rather ambiguously. "There is only one month to construct the Turkey we are dreaming of. I want you to give us sole authority to design the Turkey we are dreaming of. With love and respect." 


\title{
Inveigling the Electorate
}

Null.

\section{Promotion of the Party (05.30mins)}

There is no analogy, syllogism, enthymeme (logos) and appeals to emotions (pathos), positioning himself with relation to the audience. So many idealistic promises in one swoop encompassing directly democracy and development to be realized in the long term, which might have sounded vacuous for an ordinary citizen in the midst of terror actions.

\begin{abstract}
...There is only one party to solve the problems of Turkey.... in the first 100 days first, we will pay one month extra wage every Ramadan and Kurban Bayram; second, we will issue the family insurance law, thus every family will get at least 750 TL... we will issue the Political Ethic Law...(Economic aid commitments to individuals, students, small and medium-sized enterprises, peasants)...Turkey will be a developing country competing with the World... We will restructure the education system... State will provide free lunch to all school children... We will abolish YOK (Higher Education Council) and bring autonomy to universities. In CHP's rule Turkey will impress the World agenda with great discoveries not with illegally built palaces... (reforms in media an internet) In this country nobody will be 'reasonable guilty', everybody will be a first class citizen... Under CHP rule there will neither be streets smelling of pepper gas, neither there will be journalists, writers, scientists prisoned because of their thoughts... We will provide international standards for free expression of thoughts and freedom of information... We will provide social peace and end fight among brothers. Nobody will feel the other as 'the other'.
\end{abstract}

\section{Condemnation (03.56 mins)}

The CHP Leader spends 3.56 minutes criticizing the state Turkish Radio and Television (TRT), the AKP and the lack of democracy in the country. He reads the law, gives the time allocated to the parties in the last 25 days and the money paid to the state channel TRT from the pockets of the citizens and condemns AKP. The state channel TRT received continuous criticism from the opposition for serving AKP and not representing all other parties. All these complaints, which is true and openly implies lack of media freedom 
and democracy, might have sounded vacuous and too ideological for an ordinary citizen in the midst of terror actions. The speaker focuses his criticism on the AKP (as CHP repeatedly does) mostly on the lack of democracy, corruption and poor governance. We assume that in the midst of increasing terror actions, constant criticisms of the AKP, which lacks emotion (pathos) and striking persuasive appeals (logos) might have had vacuous impact on the mental frames of the electorate.

\begin{abstract}
...I am addressing you from the TRT screen... This TRT is broadcasting against the law and is biased promoting just one party's interests... I want a Turkey creditable in the region and the world, rich and powerful. I want a Turkey who will not be identified with corruptions, prohibitions, terror, but with democracy...(He refers to the gender equality, unemployment, dying of young people during protests, and wants a peaceful Turkey)... A party, which is the source of all these problems cannot solve the problems of Turkey. Politics is not a place to make a living, it should not be done by building palaces and waterside mansions for the Sultan, by forming media pools. politics is for serving people.
\end{abstract}

\title{
Women Issue (00.01 $\mathrm{min})$
}

I want a Turkey where gender equality is ensured and our women could take part in all areas of life.

The social democratic party CHP, which should be a keen advocate of gender equality describes the party's ideology about women's issues in a single routinely stereotyped sentence, which might have sounded unmarked and lost among many other promises given in one swoop.

Data obtained as a result of critical discourse analysis of the propaganda speech of the HDP Spoke Person Pervin Buldan broadcast in the State Television Channel TRT1 focusing mainly on "women issue":

\section{Stability for a Democratic Turkey (01.17mins)}

'1 November' is used as the metonymy of a door leading to a democratic Turkey, where peoples of Turkey can live within all their differences on the basis of equal citizenship. In the context of peace and democracy, the speaker's main concern is on 
equality of peoples and genders. Contrary to the AKP speaker who portrays a powerful government to establish security, HDP speaker focuses on the ideological outcomes of a long term reformist restructuring, which reflects the cultural and political mission of the party (BDDT). She situates her discourse on local democracies as well national (SMT). In this sense, stability and security can be established by democratic reforms. We can label these demands under the label of 'ideal' rather than 'practical' and 'pragmatic'.

7 June election was a turning point, in which our people said "yes" to peace, democracy and justice. HDP always advocated peace under every condition...we organized peace meetings. Because democratic policy is only possible in an environment, where people speak, not guns. We need real democracy and the greatest peace for this land together. You are not without alternatives. You are not obliged to carry robbers, tyrants on your back... the only formula is democracy, justice and peace. We are ready to take responsibility to provide an everlasting peace, deep-rooted democracy, local democracy, gender equality in every area, social rights of the retired, security in work and life conditions, protect ecologic life, freedom for all the oppressed. 1 November can open a door for a democratic Turkey where we can live within all our differences on the basis of equal citizenship...Let us open this door together.

\section{Exhortation for Voting (00.20 mins)}

She condemns war and encourages his electorates to vote for restarting the "peace process", which posits an ideally stereotyped picture for Turkey (democracy, gender equality, justice and peace).

Our people should respond to the Government (by their votes) that is vigorously fighting. We believe that these peace votes will cause the peace process to restart. You are not without alternative...

\section{Promotion of the Party (02.07 mins)}

The speaker figures an ideally stereotyped democratic picture for Turkey, which the party takes ideal, typical or normal (FWT). 
My beloved citizens, The Government is trying to oppress our life styles by conflict policies, which we won by 7 June elections... In that election we had made a call for a democratic Constitution, limitless speech, thought, media, demonstration freedom... We had made a call for the autonomy of villages, provinces, cities... diffusion of democracy into the roots of the public, self-management, pluralism, rights for education in the native languages of all peoples, freedom to all beliefs, elimination of a single man rule and assimilation... We had a call for secure life styles, electricity, water, housing, education and health services free of charge... making the lives of our disabled citizens able... agricultural reform, for the workers.

\section{Inveigling the Electorate (00.15 mins)}

Starting the propaganda speech with the native language of the Kurds is in itself a temptation to draw Kurdish votes, which also gives an indirect hint for the Party's core ideological priorities in Turkey. They demand education of the Kurdish public in their native language, local democracy, autonomy or separation.

Gelen me yên bi rûmet û hevalên hêja ez we hemûyan digel rêz û hezkirinên xwe bi dil can silav dikim. / My beloved people, my beloved friends I greet you all with my most sincere feelings, respect and love.

\section{Condemnation (01.47 mins)}

The "Palace" metonymy (President Erdoğan) is the central focus of accusation for the ban of 'peace process' activities, all the accusations projected directly or implicitly are long term ideals of the Party. In other words, the party is mainly concentrated on the problems of Kurdish population and implies self-rule, democracy, pluralism and recognition of their identities.

...We destroyed the antidemocratic dictatorial 10\% threshold (and won 80 seats in the Parliament)...The Palace (The president Erdoğan) and the Government could not tolerate this result, spent all their energy to exterminate HDP by ending the 'peace process' and declared war (against Kurds)...Why did the 'peace process' end?... Our Mayors were detained. How will this fight end? How will we return to the 'peace table' before the November 1 election, Erdoğan had ended the 'peace process' under the pretext that there is no Kurdish problem. Now they put the 'peace process' into the refrigerator to bring back the single government rule by fights and violence... 


\section{Women Issue (04.06 mins)}

HDP projects a perspective of building a democratic nation where gender differences coexist upon free will on the basis of equality. Gender equality is the core priority of the party (BDDT) as it denotes to more democracy. I strongly claim that the party carries out its political work for the future of the Kurds on political and gender freedom paradigm. We cannot evaluate these commitments in the context of pragmatic practicality, which simply refers to practically pragmatic solutions for the current problems. They are highly idealized, imaginary picture of advanced democracy. They appeal to reason rather than emotions (logos).

...Women coalesced in HDP and gained seats in the Parliament. We make a call for the removal of all kinds of violence to women, equal gender rights to be the basis of women's freedom and foundation of a Ministry of Woman... AKP governance manifested itself on us women as death, sexual and physical violence. War means for women expatriation, poverty, not getting education, unemployment and empowerment...War means for us...the murder of Dilek Doğan by a police bullet... all the women we lost in the Ankara Peace Meeting... We women want our sisters and brothers, our beloved ones to grow up, not to be victims of a filthy war... We know that without women peace will not come and a more just and independent life will not be established... HDP is the only party that reflects the women's will for peace...Dear women, AKP will take its place in history not only with its war policies but with its hostility against women...During AKP rule female murders increased 1400 percent.. This party does not believe in female and male equality. A government, which announces that 'A woman who is raped should give birth to the child, the state will undertake care of the child,' 'women violence is exaggerated' cannot protect the lives of women...Let us come hand in hand and walk against women's enemies, dark mentality for the freedom of women, for a greater humanity and a greater peace. Come, let us build a Turkey in which we will make a claim for our bodies, identities and a peaceful life.

Data obtained as a result of critical discourse analysis of the propaganda speech of the MHP Spoke Person Semih Yalçın broadcast in the State Television Channel TRT1 focusing mainly on the "promotion" of the MHP. 


\section{Stability for Security (00.49 mins)}

MHP's call for stability is contextually symbolic, commonplace and ungrounded. MHP implicitly reflects the party's stern and uncompromising mission about terrorism and corruption (BDDT), but their rhetoric are not compatible with logic. It does not have a strong persuasive appeal.

We shall establish peace and security permanently everywhere in Turkey... My beloved citizens, 1 November 2015 election is important for the future of Turkey. You will decide whether our country will be split up; whether terror, bribery, corruption, day to day survival worries will stop...Vote for stopping conflict, fighting and confrontations.

\section{Exhortation for Voting (00.23 mins)}

MHP is a nationalistic, pan-Turkist right wing party focusing on Turkish identity as well as Islam. Although the language of the party's political discourses reflects this in the most extreme tone, it is lacking mythic persuasive appeals. The speaker just puts a counter-position.

Vote for MHP. We expect that your votes will maintain our 1000 years old brotherhood. Vote for peace, for your future. I wish Allah will bring peace, comfort and joy to Turkey.

\section{Promotion of the Party (05.13 mins)}

The Party gives so many promises at one swoop, which might have sounded so much in the air for an ordinary citizen in the midst of chaos. However, we can evaluate the election promises from the point of party ideology.

My dear citizens, MHP is waiting for you to give us a mission to solve the problems of Turkey and to make Turkey a respectable, esteemed and developed country with great projects... From this perspective, MHP is the only party that will end terror...If you authorize us, we will make economic reforms in seven different areas...struggle against poverty, make reforms in taxing, labor force and agriculture. We will pay 2800 TL every year to the retired... We will increase the minimum wage 
and exempt it from tax and give $100 \mathrm{TL}$ transportation support to those who are living in big cities on minimum wage. We will provide employment for 700000 unemployed youth. ...We will erase all the health insurance debts of the unemployed youth...To end terror and restore peace we will employ 60000 personnel. We will ban university entrance exams... We will activate a system to canalize middle school graduates to higher education according to their talents... We will reconstruct The Directorate of Religion Affairs so as to include Alevite...

\section{Inveigling the Electorate}

Null.

\section{Condemnation (02.35 mins)}

There is no analogy, syllogism, enthymeme (logos) and appeals to emotions (pathos), MHP's criticism is on the deteriorating economy, mainly on the 'peace process' and the PKK terror. He calls the "Peace Process" as the "Betrayal Process", because the process betrayed Turkish identity and unity. Ideological differences among MHP, CHP and HDP manifest itself in their speeches. CHP and HDP focus on democracy whilst the MHP focuses on ethnic/racial identity and do not evaluate the deteriorating situation in the context of democracy, but in terms of lack of determination to take necessary precautions against terrorists.

...We have all seen that 'Peace Process' did not bring peace and democracy, but polarization and division. PKK started a bloody war, when they understood they could not realize their projects. However, people's common sense did not allow neither a civil war nor polarization... 'Peace Process' made Turkey open to terror and made defenseless... In spite of repeated warnings, the Government did not take the necessary precautions... The death of our 102 citizens in Ankara is the result of this dark process... Those subcontractors, who turned Turkey into a terror hell, are still hiding behind the slogans such as democracy, peace, and freedom. We will erase the roots of all kinds of terror...We see the 'Peace Process' as a 'Betrayal Process' ... The Party ruling the country for 13 years carried Turkey into darkness... For the last 10 years economic and employment equilibrium has deteriorated. Distribution of wealth is not just... There is an unemployed crowd of university graduates. 


\section{Women Issue (00.42 mins)}

Though shortly, it is the second party after HDP to refer to women's rights. Contextually we can explain this from the point of its pan-Turkist mental cognitions, because in ancient Turks women were equal to the men in family, they would work and fight with men together. In ancient Turks Han means emperor. There is a wellknown story about the Mongolian emperor Cengiz Han. In meetings he used to address people as "I am your 'Han"', then pointing to his wife sitting next to him, "and this is 'my Han'" (Hanım). 'Hanım' means today lady, wife. However, the rhetoric on women's rights does compromise a reformist ideology, but some commonplace wishes for women's rights..

We give prominence to the policies that will heighten woman's status and strengthen family institution... We will increase the number of women employed... we will support woman entrepreneurs by financial aid, $50 \%$ of it free... We will fight against gender inequality and violence against women...provide child-birth facilities for them.

\section{DISCUSSION AND CONCLUSION}

In the context of pragmatic practicality, we found that the AKP speaker tried to penetrate into the cognitive framework of the conservative audience by concentrating on facts at hand rather than long term idealistic goals. He reflected a highly reverential, powerful, conservative and religious profile.

All the other parties, in the midst of increasing terror, spent more time on the constant criticisms of the AKP, mostly on the lack of democracy, corruption, poor governance and promotion of their party ideals. We found out that AKP did its best to benefit from the situation to persuade people by using the dichotomy between crisis and stability effectively. Opposition parties who wanted to benefit from the deteriorated situation in the country conventionally criticized the ruling party and, as they routinely did, were suffocated in superfluous criticism and idealistic promises in one swoop, which might have sounded vacuous for an ordinary citizen in the midst of terror actions.

In the study we hypothesized that the party, which made the best use of the chaotic political and social situation, in other words, infused into the electorates' 
internal thought processes through a powerful Turkey image to end the crisis. In this contextual domain, we placed all the political maneuvers dealing with problems at hand into the contextual discourse domain of "pragmatic practicality". Conversely, in the broader context of 'the ideal' we chose women's rights and examined to what extent each party devoted time to the most crucial democratic challenge (gender inequality and abuse of women) in Turkey. We chose women's rights, because women in Turkey cope with problems such as gender discrimination in education and workplace, violence (domestic, physical, sexual and verbal), inadequate representation in decision making positions, which are among Turkey's most widespread human rights violations (Türkiye İstatistik Kurumu/Turkish Statistical Institute, 2016). We found that only HDP dedicated comparatively considerable time to women's rights.

Topics in political speech may influence what people see as the most important information of text or talk (Duin \& Grayes, 1988). Topics, if presented in the right time and setting with the right discourse materials (metaphor, metonymy, myth, emotional linguistic references, practical reasoning) correspond to the top levels of people's mental models. In this context, drawing on Chilton's (2014, p. 204) assumption pointing out to the "fear of intruders and unknown people", we can claim that fear and rescue dichotomy stimulated automatically mental frames of the voters and the political use of language of the AKP. The AKP categorized its political priorities over and the advantages of a powerful rule ornamented with Islamic and nationalist myths. The use of stability metaphor has different connotations in the party messages. We strongly claim that, if controlled with an effective rhetoric, crises benefit a strong government in office and further empower its status (Aristotles, 1992). We have also to point out to the propaganda performance of the AKP during the political campaign. Based on Van Dijk's (2010, p.10) hypothesis on context: "It is not social situation that influences (or is influenced by) discourse, but the way the participants define such a situation", we can claim that AKP made the best use of the situation in evaluating it in their own context.

We can summarize three robust findings in the study closely related to the AKP's rhetorical activism, which comprises pragmatic practical goals versus idealist goals. The AKP 1) pragmatically reinforced the importance of stability by associating it to the fear of enemies and crisis in the country by creating a strong dichotomy between them. 2) Framed its messages between two simplified contradictory dichotomies: 
Turkey as an island of stability versus the world in political turmoil. 3) Pragmatically invigorated conservative, religious and nationalistic electorate to vote for the AKP by flattering them and their votes with mythic and religious terminology, thus activating the emotional responses in electorate's mental cognitions. On the other hand, other parties either focused primarily on more democratic and honorable Turkey or on nationalistic ideals by criticizing the government and promoting their parties in the context of their ideals.

Grant Support: The author received no financial support for this work.

\section{REFERENCES}

Aristotle. (1992). The art of rhetoric (H. Lawson-Tancred, Trans.). London, UK: Penguin Books.

Black, C. J. (2011). Politicians and rhetoric the persuasive power of metaphor. Basingstoke, UK: Palgrave Macmillan. Carpio, X. V., \& Wagner, M. C. (2015). The impact of Syrian refugees on the Turkish labor market : The impact of Syrians refugees on the Turkish labor market. Policy Research working paper; no. WPS 7402. Washington D.C., USA:World Bank Group. Retrieved from http://documents.worldbank.org/curated/en/505471468194980180/ The-impact-of-Syrians-refugees-on-the-Turkish-labor-market

Charteris-Black, J. (2014). Analyzing political speeches: Rhetoric discourse and metaphor. London, UK: Palgrave Macmillan.

Chilton, P. (1985). Words, discourse and metaphors: The meanings of deter, deterrent, and deterrence. In P. Chilton (Ed.), Language and the nuclear arms debate (pp. 27-103). London, UK: Pinter.

Chilton, P. (2014). Language, space and mind: The conceptual geometry of linguistic meaning. Cambridge, UK: Cambridge University Press.

Duin, A., Roen, D., \& Graves, M. (1988). Excellence or malpractice: The effects of headlines on readers' recall and biases. In J. Readence, \& S. Baldwin (Eds.), Dialogues in Literacy Research (pp. 245-250). Chicago, USA: National Reading Conference.

Edelman, M. (1977). Political language words that succeed and policies that fail. New York, USA: Academic Press.

Fairclough, I., \& Fairclough, N. (2013). Political discourse analysis: A method for advanced students. New York, USA: Routledge.

Fairclough, N. (1989). Language and power. London, UK: Longman.

Fairclough, N., \& Wodak, R. (1997). Critical discourse analysis. In Van Dijk, T. A. (Ed.), Discourse studies: A multidisciplinary introduction (pp. 84-258). London, UK: Sage.

Gee, J. P. (2011). How to do discourse analysis. London, UK: Routledge.

Gibbs, R.W. (1996). Why many concepts are metaphorical. Cognition, 61, 309-319. Retrieved from http:// psychology.illinoisstate.edu/jccutti/psych480_24/readings/gibbs1996.pdf 
Harman, G. (1976). Practical reasoning. The Review of Metaphysics, 29(3), 431-463.

Lakoff, G. (1993). The contemporary theory of metaphor. In A. Ortony (Ed.), Metaphor and thought (pp. 203-251). Cambridge, UK: Cambridge University Press.

Lakoff, G., \& Johnson, M. (1980). Metaphors we live by. Chicago, USA: University of Chicago Press.

McGlone, M. S. (1996). Conceptual metaphors and figurative language interpretation: Food for thought. Journal of Memory and Language. 35(4), 544-565.

Smitherman, G., \& Van Dijk, T. A. (1988). Discourse and discrimination. Detroit, USA: Wayne State University Press. Sperber, D. \& Wilson, D. (1995). Relevance communication and cognition. Cambridge, USA: Blackwell Publishers.

Turkish Statistical Institute. (2016). Women Statistics: 2015 (Publication no: 21519). Retrieved from http://www. tuik.gov.tr/PreHaberBultenleri.do?id=21519

Van Dijk, T. A. (1989). New developments discourse analysis (1978-1988). Gazette, 43, 229-253.

Van Dijk, T. A. (1998). Ideology: A multidisciplinary approach. London, UK: Sage Publications.

Van Dijk, T.A. (2002). Political discourse and political cognition. In P. A. Chilton \& C.Schäffner (Eds.), Politics as Text and Talk. Analytical approaches to political discourse (pp. 204-236). Amsterdam, Netherlands: Benjamins.

Van Dijk, T. A. (2008). Discourse and context: A sociocognitive approach. Cambridge, UK: Cambridge University Press.

Van Dijk, T.A. (2010) Political identities in parliamentary debates. In C. Ilie (Ed.), European parliaments under scrutiny.Discourse strategies and interaction practices (pp. 29-56). Amsterdam, Netherlands: Benjamins.

Yetkin, M. (2016, 23 February). Erdoğan has to find an exit from the Syria situation. Hurriyet Daily News. Retrieved from http://www.hurriyetdailynews.com/opinion/murat-yetkin/erdogan-has-to-find-an-exit-from-the-syriasituation-95558 


\section{TABLES AND FIGURES}

\section{Table 1: Time Devoted to Each Topic of AKP}

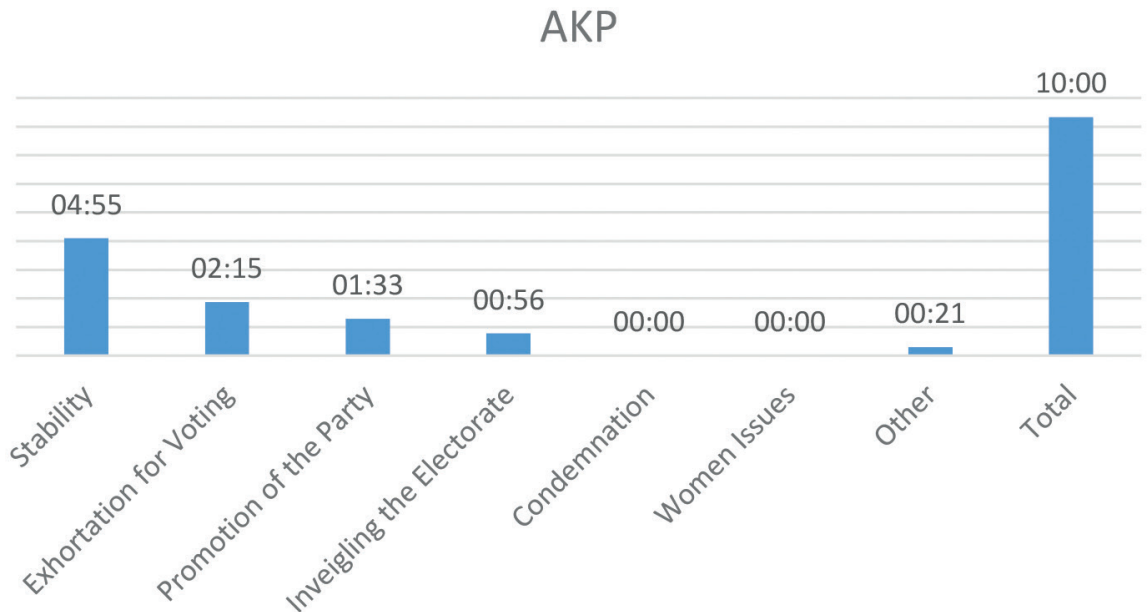

- Speech...

\section{Table 2: Time Devoted to Each Topic of CHP}

$\mathrm{CHP}$
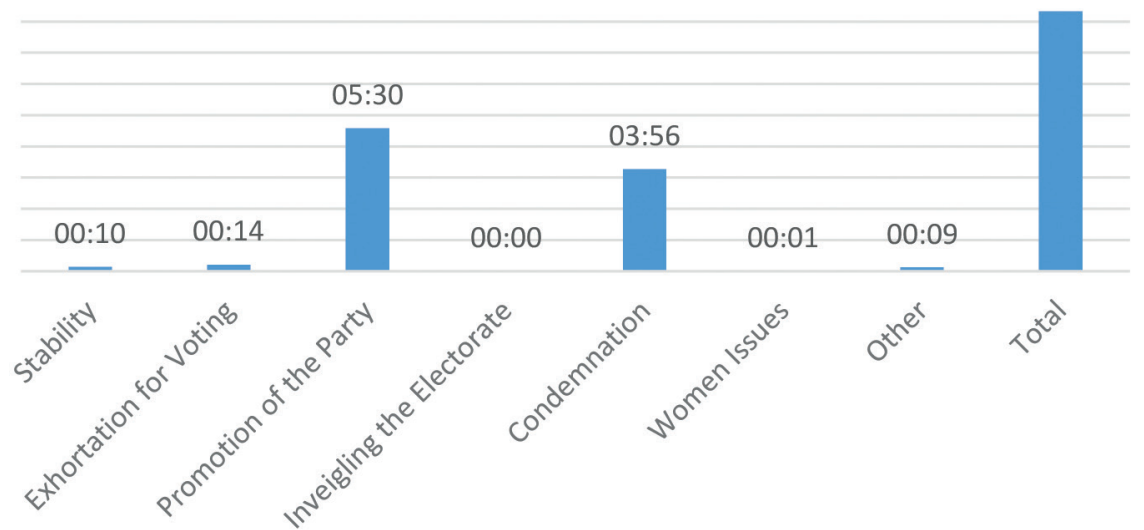

$a^{x e^{2}} \quad \mathrm{ros}^{x^{2}}$

Speech.. 


\section{Table 3: Time Devoted to Each Topic of HDP}

\section{HDP}

10:00

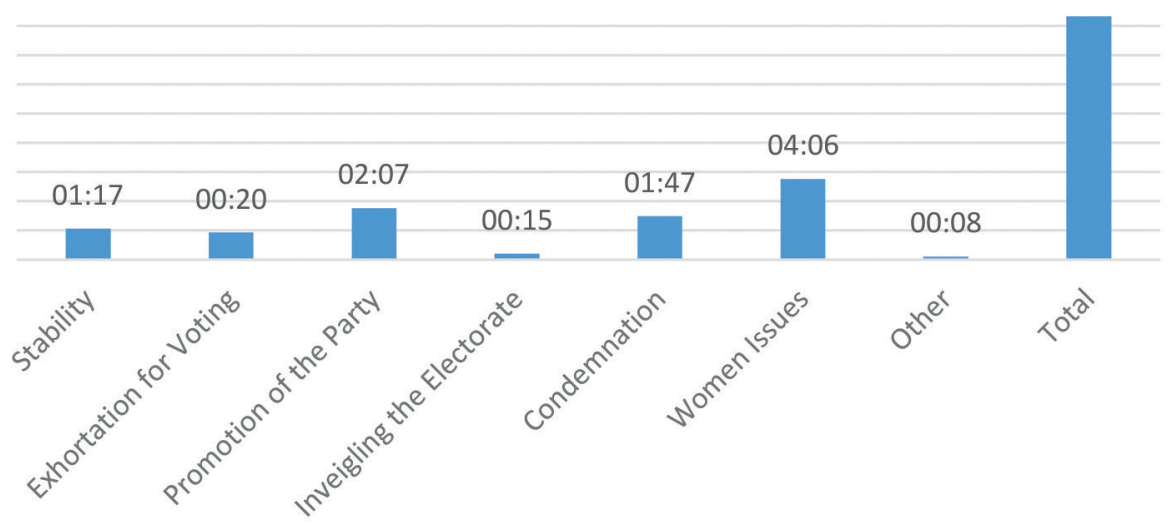

- Speech...

\section{Table 4: Time Devoted to Each Topic of MHP}

\section{MHP}

10:00
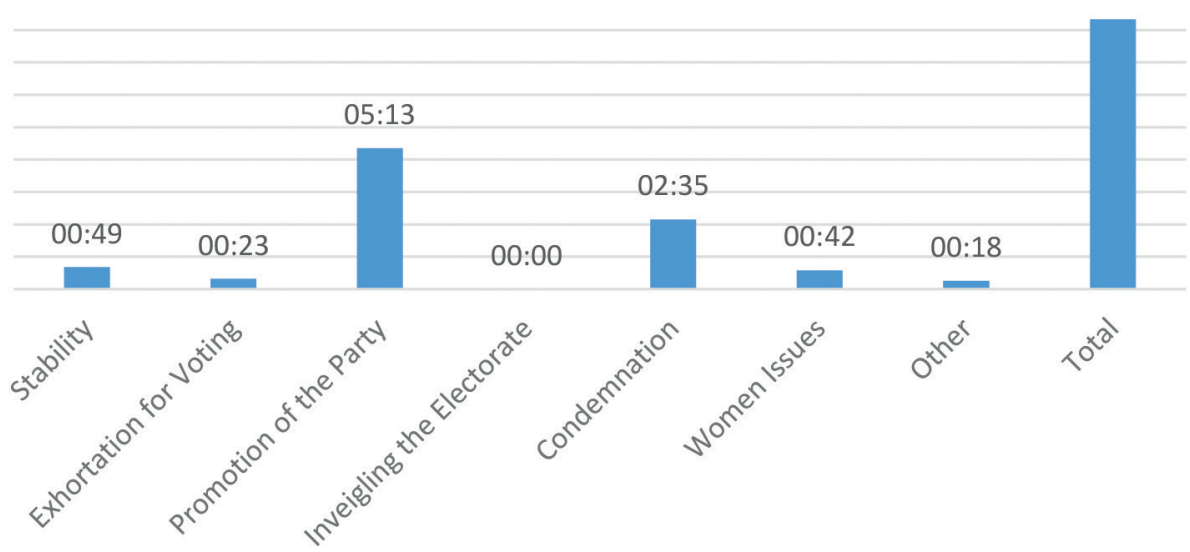

- Speech... 
Table 5: Messages in the Context of Pragmatic Practicality

AKP

\begin{tabular}{|c|c|}
\hline 09:39 & \\
\hline & $00: 21$ \\
\hline
\end{tabular}

Pursuit of Populist Pragmatist Other

Practicality

- Speech Length 